gut, possibly of no consequence, but perhaps liable to pressure if the colon became much distended. This decided me to open the large intestine. No elastic ligatures were used, as in Mr. Robson's case, as it was thought that a thorough sponge packing of the abdomen would prove effectual in keeping the peritoneum from being soiled, and 2.leo that the insertion of a Senn's plate directly the gut was incised would offer a firm point for sponge pressure whilat the gall.bladder was being prepared. This expectation was fully realised, and the ultimate result proved satisFdicory to both patient and surgeon. ${ }^{7}$ These biliary fistulæ are rare; for, as a rule, after the operation of cholecystotomy, unconnected with malignant disease, the wound heals quickly and well provided that the common bile-duct is patent. For this reason I would impress upon you the desirability of counselling patients, when sufficient evidence has accumulated to make the diagnosis of retained gall-stones possible, to submit to the operation for their removal. For, as in other chronic diseases of the internal organs in which time, rest, and climate fail to relieve, surgery must be resorted to for palliation or cure. The irritation caused by the retention of one or more gall-stones may possibly be a factor inducing malignant disease of the liver, and a calculus firmly impacted in the common bile-duct, in its efforts to reach the duodenum, is a serious complication in cholecystotomy mecessitating crushing, as advocated by Mr. Tait, or incision and suturing of the duct as successfully carried out by Mr. Knowsley Thorntou, or a series of manipulations, such as boring or chipping off pieces of the stone to permit of its extraction, all of which may directly and indirectly result in stenosed condition of the duct, and subsequently rendering such an operation as we have been considering imperative. To describe the method here carried out I have ased the term "cholescystocolotomy" in preference to thas of cholecystenterostomy, employed by other writers, as pointing out definitely that the fistula was established in connexion with the colon.

In conclusion I have to express to my house surgeon, Mr. James Lea, B.A., M.B. Cantab., the indebtedness of the patient and myself for the time, the skill, and unremitting attention he so willingly devoted to the case.

" The total loss of weight from May to the end of December was just under two stones.

\section{ON AMPUTATION AT THE HIP-JOINT; WITH RECORD OF TEN CASES.}

BY RICHARD DAVY, F.R.C.S. ENG., F.R.S.E, SURGEON TO 'LHE WESTMINSTXR HOSPITAL.

For fifteen years I have been most interested clinically in coses of hip-joint disease that demand surgical severity. I srast that a summary of my experience may have a practical value, and may render somewhat less the anxiety and responsibility of surgeons undertaking this the gravest amputation of all--viz., amputation at the hip-joint. The gravity of such procedure ought to forcibly impel surgeons to take measures to prevent its necessity. Early diagnosis of ilio-femoral disease, intelligent treatment, and perseverance with general and local measures should be written in bold type on the title-page of its history. Yet, in spite of warning, care, and weariness of well-doing, cases eventuate whose only solution rests in ablation of the joint or of the limb. Traumatism plays an important initial part; insanitation and poverty supplement it; an amputation at the hip-joint amongst the well-to-do classes is almost an. known, bearing out the accepted dogma, that "circum. stances alter cases." Leb us take an instance where con. tinued and exhaustive suppuration, hectic, hill and dale on the temperature chart, emaciation or commencing lardaceous disease of the viscera compel interference ; then as a rule it is better to excise the joint in view of giving a patient the chance of improving, and as a preliminary step in any future operation. Yet personally I do not view excision of the hip-joint very favourably in any but young subjects; children up to and below ten do admirably after excision of the hip; over that age the dangers are greater, and the ultimate usefulness of the limb not so good.

The record of my own personal experience shows that I have operated on ten patients in fourteen years, all except one bave been markedly inveterate cases of morbus coxæ; four of them had suffered excision prior to amputation at the hip-joint, profuse suppuration and resultant enfeeblement have been the immediate conditions necessitating amputation; all these doubly operated upon patients have recovered, one good argument in favour of subdividing an amputation at the hip-joint into two stages, as adrocated by Keetley ; the mortality is 20 per cent; both were men, aged twenty-nine and forty-three respectively. Two of the patients have subsequently died, one eleven, the other eight years after operation. The first of these (Case 2 on the table) was supposed to have had lardaceons disease of his viscera, at any rate he had copious albuminuria and epithelial casts in his urine in 1878. In speaking of this boyin 1880 it was remarked : "This boy had lardaceous disease of his viscera, with distressing ascites. The rectal lever was used. It would have been impossible to compress his aorta or common iliac artery through the abdominal wall, by reason of the distension. This boy's recovery is pleasing, and the albumen in his urine is daily diminishing." On April $7 \mathrm{th}, 1890$, he was readnitted into Westminster Hospital from Dr. Barnardo's Home, the subject of urgent and uncontrollable sickness, with a puffy and discharging right stump of thigh, and an cedematous foot (left). His urine was albuminons, alkaline; sp. gr. 1016. The patient passed about $11 \mathrm{oz}$. of urine in twenty.four hours, and there was persistent diarrhces. On May lst a piece of bone was removed from the stump and sinuses were laid open. $\mathrm{He}$ got weaker, duller, and more helpless, dying on May 23rd, 1890, Appended are Dr. Hebb's notes of the necropsy. "These I need not state fully, but will give an excerpt. The kidneys weighed $9 \frac{1}{2}$ oz. and $910 z$.

Ten Cases of Amputation at the Hrp.yornt.

\begin{tabular}{|c|c|c|c|c|c|c|c|c|}
\hline Za. & Sex. & Aye, & $\begin{array}{l}\text { Date of } \\
\text { anission. }\end{array}$ & Nature of disease. & Operation. & Departure. & Result. & $\begin{array}{l}\text { Blood } \\
\text { lost. }\end{array}$ \\
\hline$i$ & Boy & 9 & July coth, 1876 & Morbus coxæ (right). & Jan. 16th, 18\% & May $16 \mathrm{th}, 18 \mathrm{r}$. & Recovery. & $1 \frac{1}{2} 0 z$ \\
\hline 2 & Boy & 5 & Aug, xath, 1878 . & $\begin{array}{l}\text { Morbus coxa (riglit). } \mathrm{Ex}- \\
\text { cision previously. }\end{array}$ & July 10th, 1879 & Oct. 21st, 1879 & Recovery.* & $1 "$ \\
\hline 3 & Boy & 3 & Yow. 98th, 1879. & $\begin{array}{l}\text { Caries, Left disloeation. } \\
\text { Sequel of scarlet fever. }\end{array}$ & Jan. 20 th, 1880 & June 24th, 1880. & Recovery. & 5 \\
\hline 4 & Man & 29 & Junt oth, 1880. & Pelvic necrosis (left). & Oct. 15 th, 1880 . & Oct. 15th, 1880 . & $\begin{array}{l}\text { Death from shock } \\
\text { in } 5 \text { hours. }\end{array}$ & $4 "$ \\
\hline 5 & Doy & 16 & Avril 18th, 1882 & $\begin{array}{c}\text { Fxcision, July 11th, 18E? } \\
\text { (right). }\end{array}$ & Nov. 21st, 188:. & Feb. 24 th, 1883 & Recovery. & $1 \frac{1}{2}$ \\
\hline 3 & Girl & 18 & $0, x \mathrm{tl}, 1885$ & $\begin{array}{l}\text { Old dislocation at } 2 \text { years oll } \\
\text { (left morbus coxe). }\end{array}$ & Nov. 13th, 1883. & Marcin 28th, 1834. & Recovery. & 21 \\
\hline 7 & Girl & 23 & J). 6.th, 1885 . & $\begin{array}{l}\text { Excision of right hip joint, } \\
\text { Jan. } 2: \text { nd, } 18 \varepsilon 3 . \text { Flail limb. }\end{array}$ & Jan. 27th, 1885. & May Ist, 1885. & Recovery. & $3 n$ \\
\hline 3 & $\operatorname{Man}$ & $\$ 3$ & Mas sxth, 1886 & $\begin{array}{l}\text { Nyecrosis of left heal, neck, } \\
\text { and shaft of femur. }\end{array}$ & June Sth, $18 s 6$. & June 9 th, 1880. & $\begin{array}{l}\text { Death from syn- } \\
\text { cope (18 hours), }\end{array}$ & $2 "$ \\
\hline 9 & Boy & 10 & (3., 21st, 1886 & Morbus coxæ (left). & Oct. $29 \mathrm{th}, 1880 \mathrm{i}$ & Jan. 25th, 1887. & Recovery. & $2 "$ \\
\hline 10 & boy & 11 & Ost. $80 \mathrm{th}, 1890$ & $\begin{array}{l}\text { Morbus coxa (left) } \\
\text { Bxcision, Nov. 9th, 1890 } \\
\text { (elastic tourniquet.) }\end{array}$ & Jan. 20 th, 1801. & April 21st, 1891. & Recovery. & 21,13 \\
\hline
\end{tabular}


right and left respectively. They are typical examples of large white kidney. None of the viscera present any of the characteristics of lardaceous disease, nor do they give any amyloid reaction with iodine." "We see therefore how difficult it is to diagnose lardaceous disease in these exhausted surgical cases. Case 5 died on Feb. 6th, 1890, eight years after operation, in the Royal Free Hospital, of pelvic necrosis. I positively declined to seo the complete post.mortem examination on this boy's bedy because the post-mortem room was filled with women. In my opinion women are quite out of place in the deadhouse of any general hospital. So, as they would not leave, I did.

Method of operating.-In 1880 (Surgical Lectures) I stated : "With reference to the method of operating I shall only advise you to exercise common sense, and apply it to each individual case; keeping the skin intact where the scrotum rabs the thigh, saving as much soft tissue as you possibly can, and having your front flap covering the wound epanlette fashion, for the production of a dependent drainage, and the utmost simplicity of future dressing." Furneaux Jordan, in recapitula ting the essentials of his operation, says, "I conclude by again repeating the principle of the operation - enucleate the bone where it is most thinly covered; cut across the sof $b$ parts where they are smallest; do not touch the bulby soft parts at the inner and upper parts of the thigh."

Professor Ollier of Lyons did this operation in 1859, but the credit of bringing the method prominently before surgeons is, in my opinion, greatly due to Furneaux Jordan. The lever or elastic tourniquet having been applied, a circular incision is made at about the upper third of the thigh, through all the soft structures down to the femur; the lower section is drawn down forcibly towards the knee, to give space for the ligation or torsion of ressels. The bone is not divided, but kept intact for future leverage in disarticulating at the hip-joint (a most valuable act of conservatism). After all vessels are carefully secured an external wound is made right down to the shaft of the femur; the muscles around the trochanter major and the shaft of the bone are freed from their attachments; utilising the under surface of the rectus femoris as a guide, divide the psoas and iliacus on the capsule of the joint, as well as the capsule itself, by a long anterior slit and two short crucial nicks. The assistant then rotates the limb outwards, and forcibly adducts the knee towards the opposite armpit to dislocate the fenur from the pelvis. By the yet further availableness of the limb and femur as a lever the member is removed by a few welldirected touches of the knife, any vessels which may have been injured are promptly secured, the acetabulum is seraped, if necessary, the wound is thoroughly syringed with hot water and corrosive sublimatesolution, stitches are pnt in, and the patient is at once conveyed to a warm bed. Use all proper speed in operating short of hurry. "Festina lente" is a good motto for convenient haste. Only one word about the lever. Nine out of these ten cases have submitted to its employment. The elastic bandage in the hands of a competent assistant is quite sufficient to control any hæmorrhage, and especially so in those cases where excision of the joint has preceded ampntation. The elastic cord must be applied obliquely, spica fashion, and be manipulated so as not to interfere with abdominal respiration. The use of the elastic cord is absolutely free from danger; that of the lever is not.

Let me correct an error that has frequently been expressed, that an amputation at the hip-joint involves a loss of nearly one-fourth of the human frame. I have already contradicted this, and can adduce chapter and verse on this point: On Jan. 20th, 189l, I amputated at the hip.joint of a boy aged fourteen. The weight of the parts removed was $4 \mathrm{lb}$. On Feb. 19th, 1891, I weighed the boy-as.soon as I felt it safe-and his body weighed $50 \mathrm{lb}$. Admitting that he might have gained $2 \mathrm{lb}$. in weight since the operation, we have the proportion of tissue removed to tissue saved as 4 to 48 . This reduces the mutilation to one-thirteenth of the boy's body - a great difference from one-fourth. The point of election (upper third of thigh) as now practised necessarily makes the comparison favourable ; for in olden days the catlin entered at the anterior superior spine of the ilium, and emerged near the tuber ischii, slap-dashing off the limb by two flaps.

On Oct. 17th, 1881, the late Mr. Shuter amputated a boy's left thigh at the hip-joint ${ }^{1}$ by a subperiosteal method. In 1882 the boy had a strong movable stump, and it had the appearance of an ampatation in the middle third of the thigh. An artificial limb was made for the boy by Mr. Gray. This was worn for five months, and it had to be discontinued by reason of a painful sinus, which opened opposite the acetabulum. The case was exhibited on Feb. $9 \mathrm{th}, 1883$. The committee appointed to report on the condition of the boy's stump state that by "the pregervation of the muscles of such a length, and with their attachments becoming 80 firmly united around a strong central cord, the result obtained approaches that of an ordinary amputation at the npper third of the thigh, in respect both to the facility of adapting an artificial limb and the power with which the patient can move this appliance when walking.'

My patients are all walking with the aid of crutches, except one, who has an artificial limb. For working folk crutches are such a support, such a warning to outsiders, so easily discarded or resumed, and so comparatively cheap, that practically they are preferred in cases of this nature,

The explanation of the reduced roortality from 60 to 20 per cent. appears to be a general one.

1. The use of anæsthetics. We are too apt to forget the benefits handed down to us by previous workers better than ourselves, and to pocket their results as if they were our own. The patient being free from pain, permits a move careful and studious dexterity on the part of the surgeon, and lessens the shock on the part of himself. 2. The more rigorous application of measures calculn ted to prevent the loss of blood; such as the lever, elastic wandage, torsion, and the composed conduct of dressers. 3. The diminished shock, by adopting the method of operating at the juncture of the upper and midale third of the thigh instead of the old high transfixion plan; the less risk of hremorrhage (primary and secondary); and the uninjured condition of parts at the inner side of the thigh, situated in the confines of Scarpa's triangle. 4. Trs proved sanitation, nursing, and bygienic surroundings; more skilful dressings; marked cleanliness and the use of the syringe. 5. The greater quiet of isolation, the carefin selection of cases for operation, and the better sustained discipline preparatory to and after the operation.

Leo me again advocate every possible trial on the part of the surgeon to prevent the necessity of reconrse to amputiontion at the hip-joint. Should such necessity occur as a lasi resource for saving life, let the operation be done on somewhat similar lines to what bas been narrated in this paper; let it be completed with resolution and composure. Then, after the daily and night]y care of sargeon and nurse, fo: may be weeks or months, the patient will be able to walk on crutches or with the aid of an artificial $1 \mathrm{mb}$, and enjoy a further lease of life.

Welbeck-street, $\mathbf{w}$.

IODODERMA, OR DERMATITIS TUBEROSA, DUE TO THE INGESTION OF IODIDE OF POTASSTTM.

\section{By NORMAN WALKER, M.I., M.R.C.P. EDIN.}

THE following case, which occurred in Dr. Unna's clinie last summer, and which Dr. Unna kindly handed over to me for investigation, is one of considerable interest, for although several cases have been elinically described, the pathological histology of the new growth has, with a very few exceptions, remained uninvestigated.

J. E-, male, aged forty-one, married, was admitted on July 21 st on account of a rapidly growing tumour situated on the lower part of the nose. He has always enjoyed good health. He has had gonorrhor at least twice, and seven months ago he acquired s sore on the penis, which, he says, healed up under the application of cupric sulphate, and gave him no more trouble. His glands are everywbere hard, but not much enlarged. He never had any cutaneons eruption or loss of hair. His urine contained no albumen. The history of the present affection is as follows:-On July $8 \mathrm{th}$, on account of a feeling of dryness and discomfort in his throat, he consulted a laryngologist, who prescribed for him a mixture containing iodide of potassium, of which he was to take doses amounting altogether to seventy-five grains a day. The throat affection improved, bat on July 13th a small nodnle appeared on the bridge of the 